\title{
A laparoszkópos készségfejlesztés eszközei - elérhető trénerek és szimulátorok
}

\author{
Jaksa László $^{1}$ - Haidegger Tamás ${ }^{1}$ Galambos Péter ${ }^{1}$ - Kiss Rita ${ }^{2}$ \\ 'Óbudai Egyetem, Bejczy Antal iRobottechnikai Központ, Budapest \\ ${ }^{2}$ Budapesti Müszaki és Gazdaságtudományi Egyetem, \\ Mechatronika, Optika és Gépészeti Informatika Tanszék, Budapest
}

\begin{abstract}
A laparoszkópos technika napjainkra a sebészeti gyakorlatban széles körben elterjedt hazánkban is, azonban hatékony és etikus oktatása komplex szimulációs eszköztárat igényel. Ezek az oktatóeszközök fizikailag megvalósított boksztrénerek vagy számítógépes szimulátorok, esetleg ezek kombinációjaként jelennek meg a piacon. Közleményünkben támpontot kívánunk adni a laparoszkópos oktatóeszközök kiválasztásához a kereskedelmi forgalomban kapható szimulátorok áttekintésével és fớbb tulajdonságaik, funkcióik szisztematikus összefoglalásával. Az egyes rendszerek jellemzése mellett értékeljük a laparoszkópos oktatásra vonatkozó szakirodalmat, és kitérünk a megfigyelhető fejlesztési trendekre. A közlemény kitér a boksztrénerek és a számítógépes virtuális valóság szimulátorok közötti különbségekre, illetve betekintést nyújt a robotsebészeti és a teljes mútéti folyamatot célzó szimulátorok világába. Orv Hetil. 2017; 158(40): 1570-1576.
\end{abstract}

Kulcsszavak: laparoszkópos oktatás, boksztréner, MIS-szimulátor, robotsebészeti szimulátor

\section{Tools for laparoscopic skill development - available trainers and simulators}

The laparoscopic minimally invasive surgical technique is widely employed on a global scale. However, the efficient and ethical teaching of this technique requires equipment for surgical simulation. These educational devices are present on the market in the form of box trainers and virtual reality simulators, or some combination of those. In this article, we present a systematic overview of commercially available surgical simulators describing the most important features of each product. Our overview elaborates on box trainers and virtual reality simulators, and also touches on surgical robotics simulators, together with operating room workflow simulators, for the sake of completeness. Apart from presenting educational tools, we evaluated the literature of laparoscopic surgical education and simulation, to provide a complete picture of the unfolding trends in this field.

Keywords: laparoscopic training, box trainer, MIS simulator, surgical robotics simulator

Jaksa L, Haidegger T, Galambos P, Kiss R. [Tools for laparoscopic skill development - available trainers and simulators]. Orv Hetil. 2017; 158(40): 1570-1576.

(Beérkezett: 2017. július 22.; elfogadva: 2017. augusztus 17.)

\section{Rövidítések}

FLS = Fundamentals of Laparoscopic Surgery (A laparoszkópos sebészet alapjai); FRS = Fundamentals of Robotic Surgery (A robotsebészet alapjai); GOALS = Global Operative Assessment of Laparoscopic Skills (Laparoszkópos készségek globális operatív értékelése); MIS = minimálisan invazív sebészet; SAGES = Society of American Gastrointestinal and Endoscopic Surgeons (Amerikai Emésztőrendszeri és Endoszkópos Sebészek Társasága); VR = virtual reality (virtuális valóság)
A laparoszkópos sebészet napjainkra széles körben elterjedt a klinikai gyakorlatban, így a laparoszkópos sebészeti készségek megfelelő oktatása és felmérése fontos kérdéskörré vált [1]. A minimálisan invazív sebészethez (MIS) szükséges koordinációs készségek nagymértékben eltérnek a nyitott mútéteknél szükségesektől. A kétdimenziós rendszereknél a kamerával történő navigációnál a síkképernyő miatt lecsökken a mélységérzékelés, és a 
tapintásból nyert információ is elvész [2]. A megfelelő ügyesség kifejlesztéséhez egy jól definiálható tanulási görbe társul, amelyen a hagyományos sebészetben alkalmazott oktatási módszerek - beleértve az állatokon vagy humán cadaveren történő gyakorlást - nem tudják költséghatékonyan és ugyanakkor kockázatmentesen végigvezetni a tanulókat $[3,4]$. Erre a problémára a sebészeti szimuláció jelentheti a megoldást, amelynek használhatóságát a laparoszkópos oktatásban több tanulmány is alátámasztja $[5,6]$. Nem egyértelmú azonban a szakirodalom alapján sem, hogy mely típusú szimulátorok igazán alkalmasak az oktatásra, illetve kevés információ áll rendelkezésre az egyes gyakorlóeszközök elérhetőségével, piaci elterjedésével, valódi képességeikkel és az árakkal kapcsolatosan.

A spektrum egyik végén az egyszerü, alacsony árú, akár otthoni használatra is alkalmas laparoszkópos szimulátorok találhatók. A szakirodalom több, nagyon alacsony költségü, nem forgalomban lévő, prototípusjellegű megoldásra rámutat, amelyek könnyen megépíthetók, viszont ezek az eszközök értelemszerúen semmilyen validáláson nem estek át, így praktikusságukkal szembehelyezkedik oktatási értékük kétségbe vonhatósága [2]. A boksztrénerek általában egyszerúbb felépítésűek, hordozhatók, és az alapvető laparoszkópos készségek fejlesztését teszik lehetôvé. Ilyenek például az eszközökkel való manőverezés és manipuláció, a vágás és a varrás. A számítógépes sebészeti szimulátorok grafikus megjelenítés és esetenként haptikus visszajelzés segítségével teremtenek virtuális anatómiai környezetet, ezzel lehetővé téve a mütétspecifikus feladatok gyakorlását az általános készségek fejlesztése mellett [7]. A számítógépes szimuláció (virtuális valóság - VR) megteremti annak lehetőségét, hogy a tanuló a mütőn kívül, kevesebb stressz mellett, a betegben okozott károsodás kockázata nélkül gyakorolhassa a laparoszkópos sebészeti technikát [8]. Az ilyen eszközök jóval komplexebbek, ennek megfelelően költségesebbek, ami sok oktatóintézetet eltántorít alkalmazásuktól, így ezek a rendszerek a medikusok és rezidensek számára itthon nehezen hozzáférhetőek [9, 10]. A szimulációra többféle megközelítés és megoldás kialakult, az egyszerű és olcsó, bár alacsony valósághűségü fizikai boksztrénerektől a kifinomult VR-szimulátorokig. Egy tanulmány szerint a laparoszkópos VR-szimulátorokon való gyakorlás többet javít a sebészeti készségeken, mint a boksztrénereken végzett feladatok, viszont az nem egyértelmú, hogy ez a fejlődéstöbblet hogyan jelenik meg a mindennapi sebészeti gyakorlatban [11]. Egy másik tanulmány a laparoszkópos sebészeti készségek megmaradását vizsgálta képzetlen tanulók esetében. Egy rövid szimulátoros képzés és teszt elvégzése után a készségek megmaradása szignifikáns volt, még az egy évvel későbbi újbóli vizsgálat esetén is [12]. Napjainkban a boksztrénerek elterjedtebbek a VR-szimulátoroknál [3]. A szimulációs eszközök oktatásbeli integráltsága szakterületenként változhat. Például az urológiában jellemzően kisebb hangsúlyt kap a szimulátorokon való gyakorlás a személyes felügyelethez képest, mint a többi endoszkópos sebészeti területen [13].

Célunk a piacon elérhető laparoszkópos készségfejlesztő szimulátorok feltérképezése, funkcióik felmérése és árkategóriákba sorolása, majd az eredmények táblázatban való összefoglalása volt. Ezzel az áttekintő közleménnyel kívánunk szakmai támpontot adni az alkalmazást fontolgató hazai intézményeknek, és hozzájárulni a magyar laparoszkópos sebészeti oktatás fejlesztéséhez.

\section{Módszer}

A kutatás során a laparoszkópos gyakorlóeszközök feltérképezéséhez elsôsorban az interneten fellelhető anyagokra támaszkodtunk, valamint a hazai és nemzetközi szaklapokban, konferenciákon megjelent kiadványokat, ismertetőket és a gyártók saját anyagait tekintettük át. A Google keresőt használtuk a következő keresőszavakkal: "laparoscopic simulator", "laparoscopic trainer", "laparoscopic trainer box", "virtual reality surgical simulator", "laparoscopic surgical simulator”. Ezenkívül a Google Scholar adatbázisában kerestünk a fent listázott keresőszavakkal.

Az eredményül kapott és releváns cikkekben előforduló rendszereket szûrtük annak megfelelően, hogy menynyire tekinthető fejlettnek az adott tréner: volt-e validálva, több helyen is használják-e, egyáltalán bekerült-e kereskedelmi forgalomba. Az egyszeri, kutatási prototípusokat elhagytuk a cikkből. Az összegyújtött rendszereket három nagy csoportba soroltuk: boksz- (pelvi) trénerek, VR-szimulátorok és robotsebészeti szimulátorok. Néhány teljes mútéti folyamatot célzó szimulátor is beemelésre került, relevanciájuk és újszerüségük okán. Ez utóbbiak a teljes mútéti személyzet együttmúködésének fejlesztését célozzák. Minden rendszernél feltüntettük a gyártót (fejlesztőt), a tréner típusát, használati módját, fontosabb paramétereit, és ahol volt adat, a közelítóleges árat is.

Egy-egy tréner használhatóságát általában jól mutatja a korábbi validációs kísérletek eredménye - ha voltak ilyenek -, ezért ezt igyekeztünk minden rendszernél feltüntetni, amennyiben volt erre vonatkozó adat. A készségfelmérés egységesítését célzó, a Society of American Gastrointestinal and Endoscopic Surgeons (SAGES) által létrehozott Fundamentals of Laparoscopic Surgery (FLS) program gyakorlati készségeket fejlesztő és mérő modulja öt feladatot tartalmaz: peg transfer, minta kivágása, elkötő hurok használata, varrás intracorporalis csomóval, varrás extracorporalis csomóval [6]. A Fundamentals of Robotic Surgery (FRS) az FLS robotsebészeti változata. Ebben a sebészeti robottal és FRS-dómmal végzett gyakorlatok mellett virtuális robotsebészeti szimulátoros feladatok is szerepelnek. Az FRS hét feladatot tartalmaz: eszköz bevezetése, peg transfer, csomózás, kötött pálya lekövetése, vágás a negyedik robotkarral, minta kivágása, ér lezárása és vágása (frsurgery.org). 


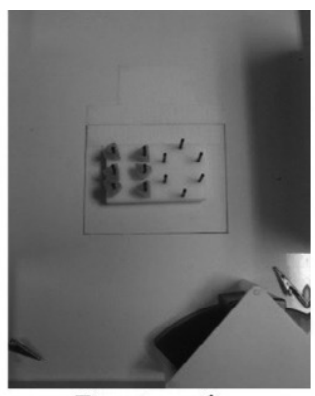

Peg transfer

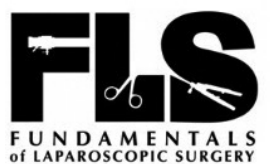

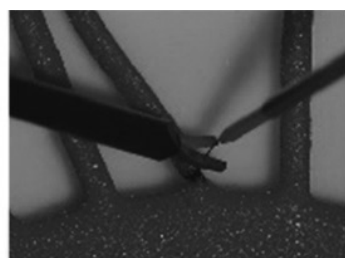

Elkötő hurok

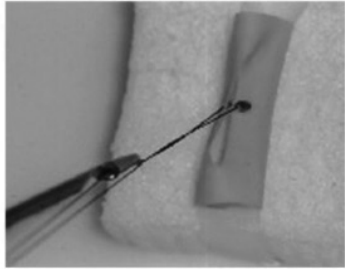

Extracorporális csomó

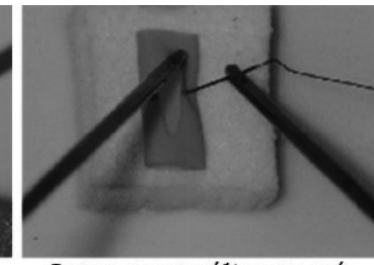

Intracorporális csomó

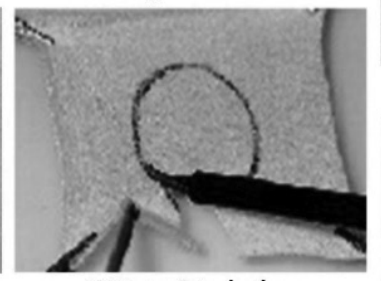

Minta kivágása
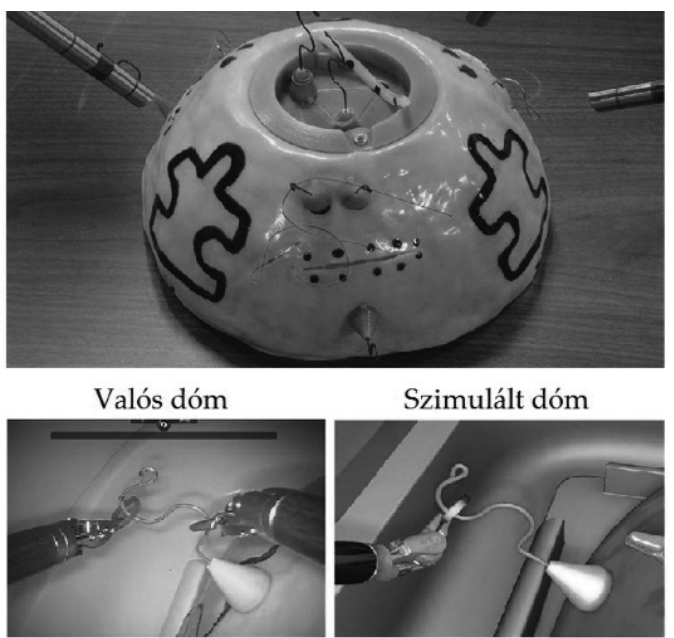

Szimulált dóm

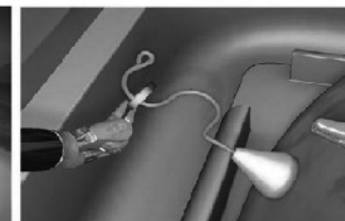

A választott készségfelmérési módszer nagyban befolyásolja, hogy milyen készségszintek minősülnek elfogadhatónak, így a megfelelő mérési módszer megválasztása kulcsfontosságú a sebészeti oktatás minőségének biztosításában [14]. Steigerwald és mtsai laparoszkópos gyakorlattal rendelkező alanyokon végzett kísérletében sem a box traineres gyakorlás, sem a LapVR (CAE Healthcare) VR-szimulátoros gyakorlás nem mutatott szignifikáns korrelációt a Global Operative Assessment of Laparoscopic Skills (GOALS) értékelési rendszerben elért pontszámmal [15]. Ez intő jel arra, hogy ezek a módszerek nem feltétlenül alkalmasak gyors képességfelmérésre vagy szelekcióra.

\section{Eredmények}

A keresés során vizsgált laparoszkópos készségfejlesztő boksztrénerek adatait az 1. táblázat tartalmazza. Az 1 . táblázat „Tananyag” oszlopában az „FLS-feladatok” és az „alapfeladatok” között tartalmilag nincs különbség, viszont azokról az eszközökről, amelyekról nem derült ki egyértelmúen, hogy igazoltan FLS-kompatibilisek, nem jelenthető ki, hogy FLS-feladatokat tartalmaznak, ezért más notációt választottunk.

A VR-szimulátorok egyre jelentősebb részét képezik a sebészeti oktatásnak. A piacon elérhető VR-szimulátorok jellemzőit a 2. táblázat tartalmazza. Az eró-visszacsatolás (2. táblázat, 7. oszlop) alkalmazása jelenti a legnagyobb fejlődési irányt ezen a területen, mert a virtuálisan bemutatott szövetek fizikai tapinthatóságának lehetővé tétele nagyban növeli a valósághűséget és ezáltal az oktatási értéket. A VR-szimulátorok jó oktatási eredményeket biztosítanak, de költséghatékonyságuk a mai napig nem bizonyított.

Az utóbbi két évtizedben a robotikai rendszerek gyors fejlődése lehetővé tette, hogy az ipari környezet mellett az orvoslásban is szerepet kapjanak a robotok [16]. A robotos MIS egyik úttörője a da Vinci Surgical System
(Intuitive Surgical Inc.), amelyból már több mint 4000 darab szolgál világszerte. Ezzel a módszerrel a sebész távolról, egy robotszerkezetet vezérelve végezheti el a laparoszkópos beavatkozást. A robotos teleoperációs rendszerek hatékonynak bizonyultak a mútéti eredmények javításában, fooleg az urológiai és nőgyógyászati beavatkozásoknál. Napjainkban évente közel 1,5 millió páciens részesül telerobotos mütétben világszerte [17]. A robotos MIS-rendszerek tervezése és fejlesztése az általános mozgásszabályozási problémák mellett nem mindennapi kihívásokat is felvet a múködési környezetből fakadó szigorú biztonsági és kommunikációs követelmények miatt. A lágyszövetek komplex mechanikai tulajdonságai további nehézségeket jelentenek, amelyek sebészeti szimulációba való integrálása mind a mai napig nem teljeskörüen megoldott [18]. Ennek megfelelően a mérnöki kihívások mellett a robotrendszerek helyes használatának oktatása is egy nagyon összetett problémakör. A teleoperációs robotsebészeti szimulátorok (3. táblázat) nagyban elősegítik a da Vinci robotsebészethez szükséges mozgáskoordinációs készségek elsajátítását, hiszen a tanulóknak egy újfajta és feltehetően szokatlan irányítási környezetet kell megismerniük. Annak ellenére, hogy több tucat, kereskedelmi forgalomban kapható sebészrobot létezik [19], csak a da Vincihez készítettek kifejlesztett oktatórendszereket is.

$\mathrm{Az}$ ismertetett trénerek nagy része olyan szoftvereket biztosít, ahol teljes mértékben objektivizálni lehet a gyakorlatot végző teljesítményét, valamint nyomon lehet követni a fejlődését. Ugyanakkor fontos megemlíteni, hogy szimulátorok között ritka a 3D képmegjelenítés. Egy friss kutatás szerint a 3D képmegjelenítés kezdő és haladó laparoszkópos sebészeknél is szignifikáns készségjavulást eredményez a 2D megjelenítéssel szemben. Egy 3D képet néző kezdő sebész készségei vetekedtek egy 2D képet néző haladó sebész eredményeivel [20]. Romero-Loera és mtsai szerint a 3D megjelenítéssel rendelkező laparoszkópos szimulátorokon a tanulók ugyan- 


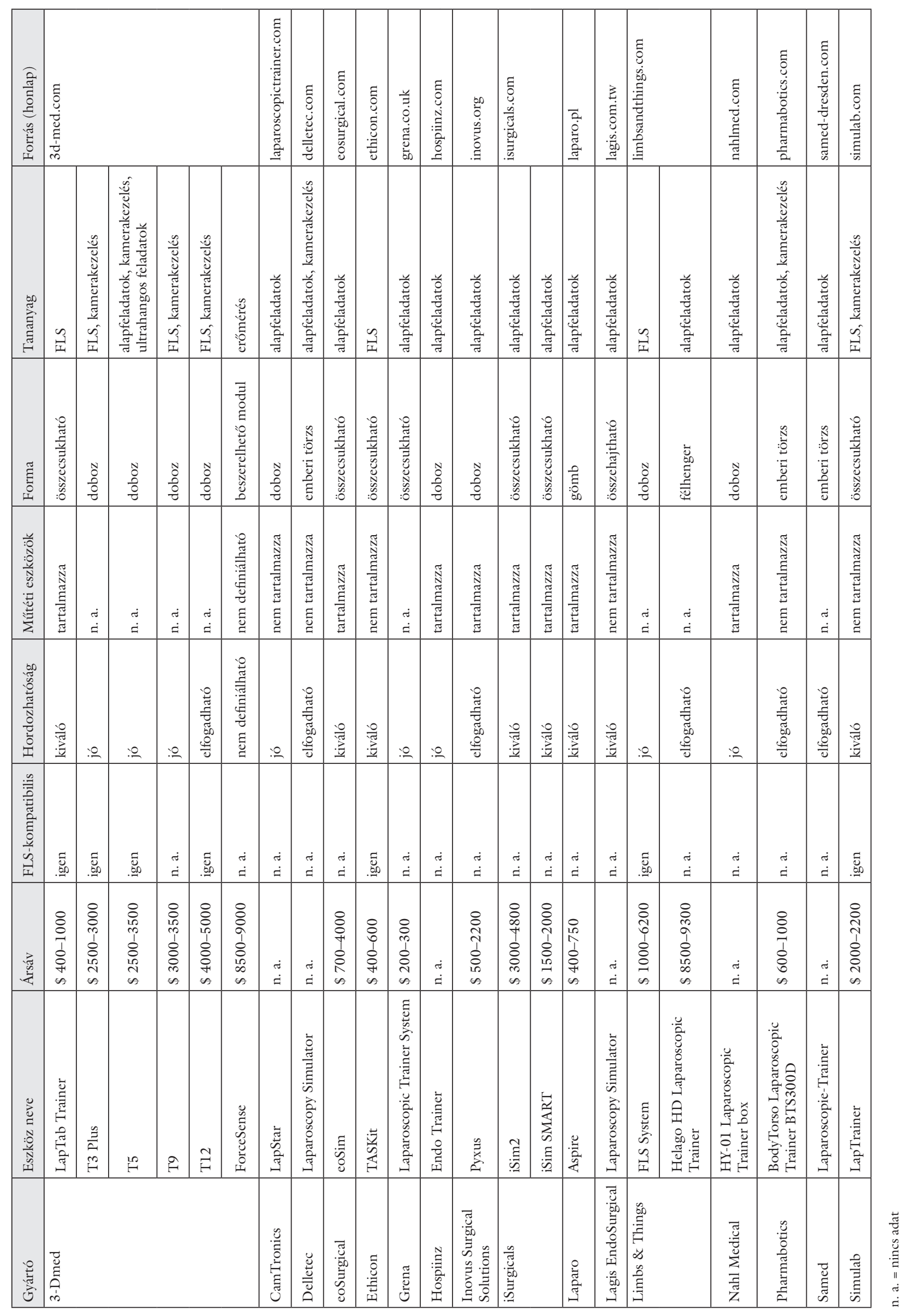




\begin{tabular}{|c|c|c|c|c|c|c|c|c|c|c|c|c|c|c|c|}
\hline 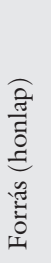 & 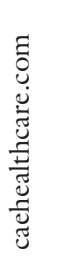 & & 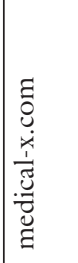 & & & 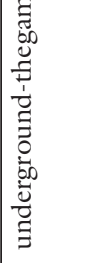 & 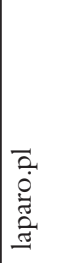 & & 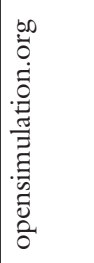 & 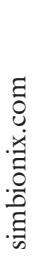 & 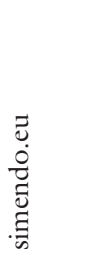 & 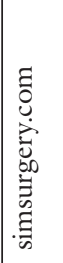 & & 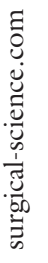 & 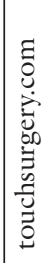 \\
\hline 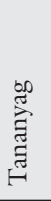 & 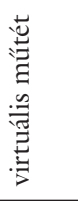 & 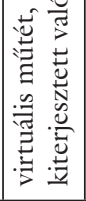 & 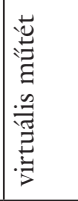 & 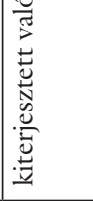 & 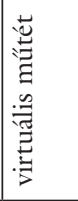 & 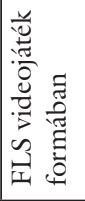 & 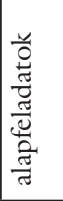 & 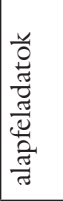 & 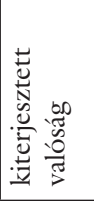 & 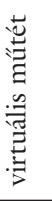 & 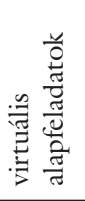 & 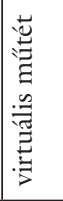 & 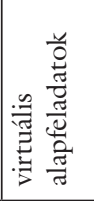 & 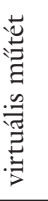 & 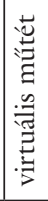 \\
\hline 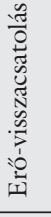 & F & 男 & 弟 & 号 & 卷 & 兽 & 总 & 总 & 号 & $\Xi$ & 号 & Еี & 泀 & Е & 节 \\
\hline 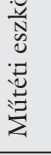 & 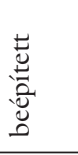 & 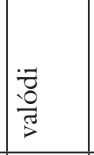 & 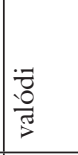 & 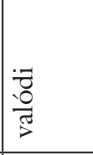 & 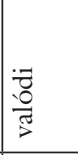 & 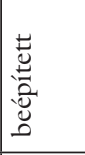 & 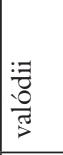 & 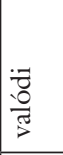 & 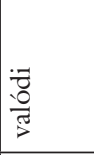 & 蒙 & 蒿 & 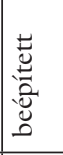 & 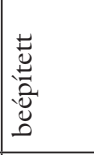 & . & 㽞 \\
\hline 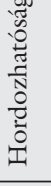 & 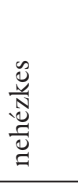 & 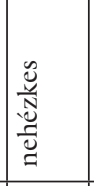 & $\because \supseteq$ & $\because \therefore$ & 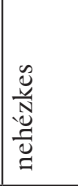 & $: \because$ & $\because 0$ & 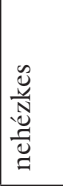 & 造 & 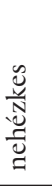 & $: 0$ & 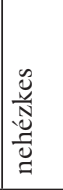 & 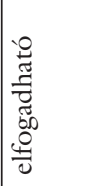 & 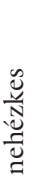 & 兽 \\
\hline 总 & : & $\begin{array}{l}\stackrel{\dot{J}}{\leftrightarrows} \\
\end{array}$ & 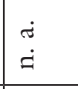 & $\stackrel{\check{J}}{\leftrightarrows}$ & 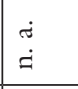 & $\stackrel{\overrightarrow{.0}}{=.0}$ & $\begin{array}{l}\dot{j} \\
\dot{I}\end{array}$ & $\begin{array}{l}\dot{\Xi} \\
\check{\leftrightarrows}\end{array}$ & 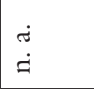 & $\stackrel{\check{J}}{\check{I}}$ & $\stackrel{\dot{J}}{\dot{\Xi}}$ & $\stackrel{\check{J}}{\check{\leftrightarrows}}$ & $\stackrel{.}{\leftrightarrows}$ & 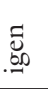 & $\begin{array}{l}\dot{\sigma} \\
\dot{=}\end{array}$ \\
\hline 橧 & $\begin{array}{l}8 \\
8 \\
0 \\
\infty \\
\infty \\
\infty \\
\infty\end{array}$ & $\stackrel{\check{J}}{=}$ & $\mid \begin{array}{l}0 \\
8 \\
0 \\
0 \\
0 \\
0 \\
0 \\
0 \\
10 \\
10 \\
10 \\
\infty\end{array}$ & 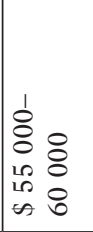 & 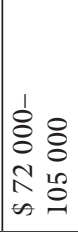 & 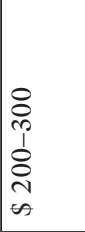 & $\begin{array}{l}8 \\
0 \\
10 \\
1 \\
0 \\
0 \\
1 \\
n \\
0\end{array}$ & \begin{tabular}{|l}
8 \\
0 \\
0 \\
0 \\
0 \\
0 \\
0 \\
10 \\
0 \\
0
\end{tabular} & $\begin{array}{l}8 \\
0 \\
0 \\
+ \\
6 \\
0\end{array}$ & $\stackrel{\text { I }}{\leftrightarrows}$ & $\begin{array}{l}8 \\
\vdots\end{array}$ & $\stackrel{\dot{\sigma}}{=}$ & 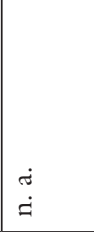 & $\begin{array}{l}8 \\
\vdots \\
i \\
1 \\
\vdots \\
\vdots \\
\vdots \\
0 \\
0 \\
0 \\
0\end{array}$ & $\begin{array}{l}\dot{\sigma} \\
=\end{array}$ \\
\hline 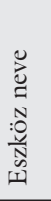 & 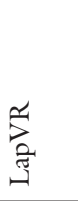 & 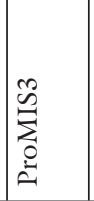 & 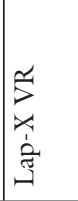 & 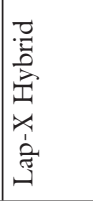 & 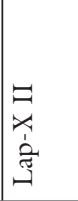 & 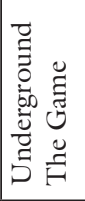 & \begin{tabular}{|l} 
峁 \\
妾 \\
\end{tabular} & 蟇 & $\begin{array}{l}\frac{\vec{z}}{2} \\
\frac{2}{3}\end{array}$ & 苛 & 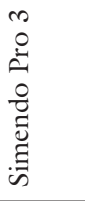 & 商 & 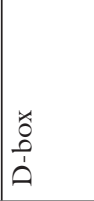 & 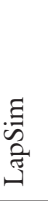 & 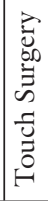 \\
\hline 憘 & 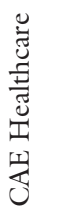 & & 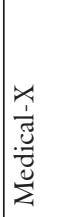 & & & 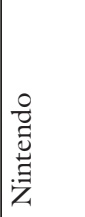 & 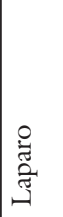 & & 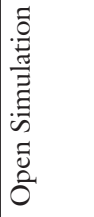 & 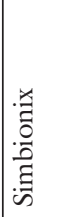 & 总 & 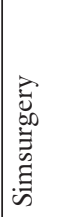 & & 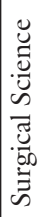 & 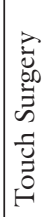 \\
\hline
\end{tabular}


3. táblázat | Robotsebészeti és teljes mútéti személyzetet célzó szimulátorok

\begin{tabular}{|c|c|c|c|c|c|}
\hline Gyártó & Eszköz neve & Ársáv & FLS-kompatibilis & Tananyag & Forrás (honlap) \\
\hline $\begin{array}{l}\text { BBZ Medical } \\
\text { Technologies }\end{array}$ & Actaeon & $\$ 30000-32000$ & n. a. & robotsebészet & bbzmedicaltechnologies.com \\
\hline Intuitive Surgical & da Vinci Skills Simulator & n. a. & igen & robotsebészet & intuitivesurgical.com \\
\hline \multirow[t]{2}{*}{ Mimic Simulation } & dV-Trainer & $\$ 60000-100000$ & n. a. & \multirow[t]{2}{*}{ robotsebészet } & \multirow[t]{2}{*}{ mimicsimulation.com } \\
\hline & FlexVR & n. a. & n. a. & & \\
\hline ORZONE & ORCAMP - MIS Setup & n. a. & n. a. & $\begin{array}{l}\text { teljes mútő } \\
\text { szimulációja }\end{array}$ & orzone.com \\
\hline \multirow[t]{2}{*}{ Simbionix } & RobotixMentor & n. a. & n. a. & robotsebészet & \multirow[t]{2}{*}{ simbionix.com } \\
\hline & TeamMentor & n. a. & n. a. & $\begin{array}{l}\text { teljes műtő } \\
\text { szimulációja }\end{array}$ & \\
\hline SimSurgery & SEP Robot & n. a. & n. a. & robotsebészet & simsurgery.com \\
\hline Simulated Surgicals & $\begin{array}{l}\text { Robotic Surgery } \\
\text { Simulator }\end{array}$ & n. a. & n. a. & robotsebészet & simulatedsurgicals.com \\
\hline Surgical Science & TeamSim & n. a. & n. a. & $\begin{array}{l}\text { teljes mútő } \\
\text { szimulációja }\end{array}$ & surgical-science.com \\
\hline
\end{tabular}

n. a. $=$ nincs adat

annyi gyakorlás után gyorsabban hajtják végre az adott feladatokat, mint a 2D megjelenítésú, síkképernyős szimulátorokon [21].

Végezetül fontos megemlíteni, hogy magasabb kognitív szinten is fontos a tanulás, a folyamatok begyakorlása. A műtéti személyzet kommunikációját, kooperációját fejlesztő szimulátorok a sebészeti oktatás új irányát képviselik. Egyre több tanulmány támasztja alá a szükségességüket, ugyanis az orvosi múhibák jelentős része a mútéti csapat nem megfelelő összedolgozásából fakad [22]. Az ilyen jellegú szimulátorokat a 3. táblázat tartalmazza.

\section{Megbeszélés}

A mútéttani módszerek rohamos fejlődésével a technika egyre inkább teret nyer a sebészeti oktatásban is. Az új módszerek és technológiák használata újszerü készségek kifejlesztését és gyakorlását követeli meg. A minimálisan invazív sebészet előretörésével párhuzamosan megjelentek a laparoszkópos oktató-gyakorló eszközök, az egyszerü boksztrénerektől a komplex, erő-visszacsatolást használó VR-szimulátorokig. Sőt újabban már az igen sikeres da Vinci robotsebészeti rendszerhez kapcsolódóan többfajta szimulátort használnak. A szimulátorok jelentősége a mútéti oktatásban egyre nő. A laparoszkópos sebészeti szimulátorokat nemcsak oktatásra, hanem mútétek előtti bemelegítésre is célszerű használni, mert az ilyen jellegü bemelegítés javítja az egyes részfeladatok elvégzési idejét [23]. Egy kutatás szerint a laparoszkópos szimulátorokon megtanult és begyakorolt készségek az artroszkópos készségekre szintén hatással vannak, azokat javítják [24]. Egy 45 publikációt felölelő tanulmány szerint sebészeti készségfelmérésnek a valós mútétek során is meg kell jelennie, illetve nagyobb hangsúlyt kell fektetni a szimulátorokon való gyakorlás valós mútéti eredményekre gyakorolt hatásának nyomon követésére [25]. Egy másik kutatás szerint a laparoszkópos készségek önálló kiértékelésének eredménye a laparoszkópos cholecystectomiában használatos alapkészségek szimulátoros gyakorlása esetében erősen korrelál a külső, tapasztalt megfigyelők által megítélt eredménnyel. Ez az olcsóbb szimulátorok otthoni, egyéni használatának indokoltságát támasztja alá [26].

Közleményünk az egyes eszközök funkcióinak, paramétereinek részletes összefoglalásával iránymutatást adhat az adott oktatási célra leginkább megfelelő szimulátor kiválasztásához, így segítséget nyújthat a magyar laparoszkópos sebészeti közösségnek.

A jelenleg már elérhető trénerek hiányzó tulajdonságait alapul véve kutatócsoportunk új oktatási eszközök fejlesztésébe kezdett [27]. A pelvi tréner helyes kialakítása mellett különösen nagy hangsúlyt helyezünk az anatómiailag helyes fantomok kialakítására, valamint újfajta teljesítménymérési eszközök és módszerek bevezetésére [28]. Egyik újabb eredményünk, hogy egy saját fejlesztésű kismedencefantom alá erőmérő cellák kerültek olyan elrendezésben, amely lehetôvé teszi a fantomra ható erők mérését gyakorlás közben [29]. Ezek a munkák a laparoszkópos készségfejlesztő szimulátorok jövőbeli fejlesztési irányait mutathatják, amelyek a következő években már bekerülhetnek a hazai mútéttani oktatásba. 
Anyagi támogatás: Jelen közlemény megírása anyagi támogatásban nem részesült. A megalapozó kutatást az Austrian Center for Medical Innovation and Technology $\mathrm{GmbH}$ támogatta.

Szerzői munkamegosztás: J. L., H. T.: A szakirodalom elemzése. A tárgyalt eszközök feltérképezése, értékelése és táblázatba foglalása. J. L., H. T., G. P., K. R.: A kézirat szövegezése. A cikk végleges változatát valamennyi szerző elolvasta és jóváhagyta.

Érdekeltségek: A szerzőknek nincsenek érdekeltségeik.

\section{Irodalom}

[1] Fábry Gy, Haidegger T. Laparoscopic skills training - novel methods. [Laparoszkópos készségek fejlesztése - új módszerek.] Orv Hetil. 2013; 154: 742-751. [Hungarian]

[2] Li MM, George J. A systematic review of low-cost laparoscopic simulators. Surg Endosc. 2017; 31: 38-48.

[3] Aggarwal R, Moorthy K, Darzi A. Laparoscopic skills training and assessment. Br J Surg. 2004; 91: 1549-1558.

[4] Suhánszki N, Haidegger T. Objective surgery - advanced robotic devices and simulators used for surgical skill assessment. [Objektív sebészet - robotok és szimulátorok használata a sebészeti képességek felmérésére.] Magy Seb. 2014; 67: 340-352. [Hungarian]

[5] Nagendran M, Gurusamy KS, Aggarwal R, et al. Virtual reality training for surgical trainees in laparoscopic surgery. Cochrane Database Syst Rev. 2013; (8): CD006575.

[6] Sándor J, Lengyel B, Haidegger T, et al. Minimally invasive surgical technologies: Challenges in education and training. Asian J Endosc Surg. 2010; 3: 101-108.

[7] Dunkin B, Adrales GL, Apelgren K, et al. Surgical simulation: a current review. Surg Endosc. 2007; 21: 357-366.

[8] Gaba DM. The future vision of simulation in health care. Qual Saf Health Care 2004; 13: i2-il0.

[9] Schijven M, Jakimowicz J. Virtual reality surgical laparoscopic simulators. Surg Endosc. 2003; 17: 1943-1950.

[10] Bernier GV, Sanchez JE. Surgical simulation: the value of individualization. Surg Endosc. 2016; 30: 3191-3197.

[11] Zendejas B, Brydges R, Hamstra SJ, et al. State of the evidence on simulation-based training for laparoscopic surgery: a systematic review. Ann Surg. 2013; 257: 586-593.

[12] Fitzgerald JE, Caesar BC. The European working time directive: a practical review for surgical trainees. Int J Surg. 2012; 10: 399_ 403.

[13] Undre S, Darzi A. Laparoscopy simulators. J Endourol. 2007; 21: 274-279.

[14] Thinggaard E, Bjerrum F, Strandbygaard J, et al. Ensuring competency of novice laparoscopic surgeons - exploring standard setting methods and their consequences. J Surg Educ. 2016; 73: 986-991

[15] Steigerwald SN, Park J, Hardy KM, et al. The Fundamentals of Laparoscopic Surgery and LapVR evaluation metrics may not correlate with operative performance in a novice cohort. Med Educ Online 2015; 20: 30024

[16] Haidegger T. The advancement of robotic surgery - successes, failures, challenges. [A robotsebészet hódítása - sikerek, kudarcok, kihívások.] Orv Hetil. 2010; 151: 1690-1696. [Hungarian]

[17] Takács Á, Nagy DÁ, Rudas IJ, et al. Origins of surgical robotics: From space to the operating room. Acta Polytech Hun. 2016; 13: $13-30$

[18] Takács Á, Kovács L, Rudas IJ, et al. Models for force control in telesurgical robot systems. Acta Polytech Hun. 2015; 12: 95114

[19] Hoeckelmann L, Rudas IJ, Fiorini P, et al. Current capabilities and development potential in surgical robotics. Int J Adv Robot Syst. $2015 ; 12: 61$

[20] Folaranmi SE, Partridge RW, Brennan PM, et al. Does a 3D image improve laparoscopic motor skills? J Laparoendosc Adv Surg Tech. 2016; 26: 671-673.

[21] Romero-Loera S, Cárdenas-Lailson LE, Concha-Bermejillo F, et al. Skills comparison using a $2 \mathrm{D}$ vs. $3 \mathrm{D}$ laparoscopic simulator. Cir Cir. 2016; 84: 37-44.

[22] Makary MA, Daniel M. Medical error - the third leading cause of death in the US. BMJ 2016; 353: i2139

[23] Da Cruz JA, Reis ST, Frati RM, et al. Does warm-up training in a virtual reality simulator improve surgical performance? A prospective randomized analysis. J Surg Educ. 2016; 73: 974-978.

[24] Akhtar K, Sugand K, Wijendra A, et al. The transferability of generic minimally invasive surgical skills: Is there crossover of core skills between laparoscopy and arthroscopy? J Surg Educ. 2016; 73: 329-338.

[25] Vedula SS, Ishii M, Hager DG. Objective assessment of surgical technical skill and competency in the operating room. Annu Rev Biomed Eng. 2017; 19: 301-325.

[26] Ganni S, Chmarra MK, Goossens RH, et al. Self-assessment in laparoscopic surgical skills training is it reliable. Surg Endosc. 2017; 31: 2451-2456.

[27] Nigicser I, Szabó B, Jaksa L, et al. Anatomically relevant pelvic phantom for surgical simulation. 7th IEEE International Conference on Cognitive Infocommunications, 16-18 October 2016, Wroclaw, Poland.

[28] Barcza Sz. Surgical skill assessment with robotic technology. [Sebészeti képességek felmérése robottechnológiai módszerekkel.] Diplomamunka, Budapesti Műszaki és Gazdaságtudományi Egyetem, Villamosmérnöki és Informatikai Kar, Irányítástechnika és Informatika Tanszék, 2016. [Hungarian]

[29] Jaksa L. Force feedback unit design for a laparoscopic surgical simulator. [Erôvisszacsatolt részegység tervezése laparoszkópos sebészeti szimulátorhoz.] Szakdolgozat, Budapesti Múszaki és Gazdaságtudományi Egyetem, Gépészmérnöki Kar, Mechatronika, Optika és Gépészeti Informatika Tanszék, Budapest, 2017. [Hungarian]
(Jaksa László, Budapest, Bécsi út 96/B, 1034 e-mail: laszlo.jaksa@irob.uni-obuda.hu) 